\title{
Horizontal Wall Movement and Ground Surface Settlement Analysis of Braced Excavation Based on Support Spacing
}

\author{
W. Hidayat ${ }^{1 *}$ \\ ${ }^{1 *}$ Department of Civil Engineering, Pertamina University \\ Email: ${ }^{1 *}$ wirman.hidayat@universitaspertamina.ac.id
}

\section{A R T I C L E I N F O \\ Article History : \\ Article entry : 28-02-2021 \\ Article revised : 12-03-2021 \\ Article received : 22-03-2021 \\ Keywords : \\ Deformation, Finite Element Method, Struts Spacing, System Stiffness.}

IEEE Style in citing this article : [1] C. $Y . O u, B .-Y$. Shiau, and I.-W. Wang, "Threedimensional deformation behavior of the Taipei National Enterprise Center (TNEC) excavation case history," Can. Geotech. J., vol. 37, no. 2, pp. 438-448, 2000.

\section{Introduction}

On deep excavation with straight vertical faces, the lateral supports, including walls and bracing systems with braced excavation methods, are generally required to prevent excessive horizontal wall movement and ground surface settlement. The increasing needs of infrastructures and limited land conditions are reasons for excavation construction to optimize land use. Regarding this condition, the dimensions and depth of excavation are also increasing, which may cause deformations, including the horizontal wall movement and ground surface settlement that occurs in the area around the excavation to increase significantly. Deformation 
Analysis in excavation construction is very important, especially for excavations with a limited working area, to prevent damage on the adjacent building due to horizontal wall movement and ground surface settlement induced by the excavation.

The stiffness of the excavation system is the structural parameter that significantly influences the deformation of the excavation. This parameter is determined by the spacing of the vertical and horizontal supports (strut), support stiffness, excavation geometry, and retaining wall stiffness. The stiffness of the excavation system is a complex model and requires good numerical accuracy. The deformation analysis using finite element analysis (FEM) has a good level of accuracy compared to empirical methods verified using field measurements[1][5].

Then it is also found that the analysis deformation using two-dimensional (2D) and three-dimensional (3D) models has differences due to the arching effect that occurs at the corner of excavation on the 3D models [1], [2], [4]-[9]. Previous studies on deformation in excavation and specific case analysis have been discussed, including analyzing the reduction of deformations [10]-[15][16].

This study presents the influence of support spacing on horizontal wall movement and ground surface settlement of braced excavation. The analysis was carried out using the FEM method in PLAXIS 2D and 3D, which is useful for analyzing the arching effect on the parametric study results.

\section{Literature Review}

\subsection{Horizontal Wall Movement and Ground Surface Settlement}

Braced excavation is a soil retaining system that has structural components, which consist of walls and bracing. This system was designed to retain the movement and provide the stability of the excavation. The braced excavation deformations include the horizontal wall movement and ground surface settlement, as seen in Figure 1 (a). Horizontal wall movement occurs on the wall in a lateral direction on the inner side of the excavation, while ground surface settlement can occur on the surface behind the wall. Previously, a method for determining the ground surface settlement profile and determining the maximum value of settlement based on the ratio to horizontal wall movement was conducted [17]. The accuracy of this method is highly dependent on the value of the deformation ratio used. The horizontal wall movement and ground surface settlement in the longitudinal direction of the wall have a small deformation value at the excavation corner and the maximum value at the center of the excavation span, as 
shown by Figure 1 (b) [18]. Semi-empirical methods using the finite element and measurement data are also provided. From the results of the semi-empirical study, it was found that the model. Created to predict the maximum horizontal wall movement and ground surface settlement for soft clay and medium clay [19].

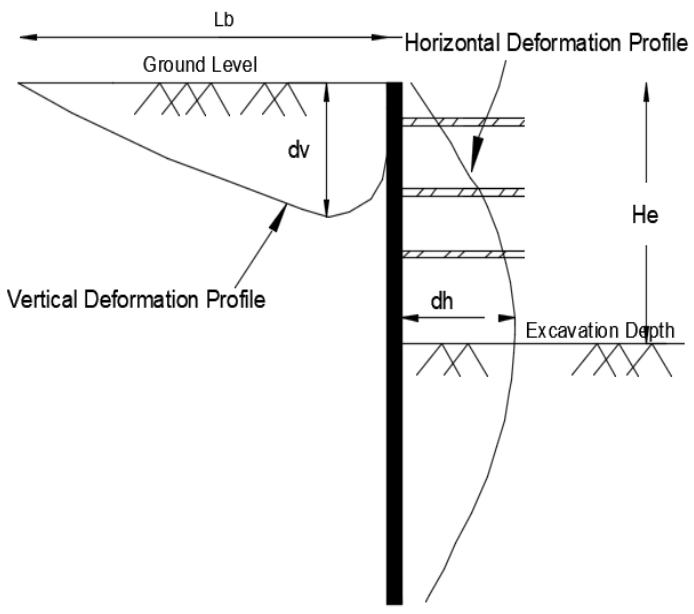

(a)

Source: (Hsieh \& Ou, 1998)

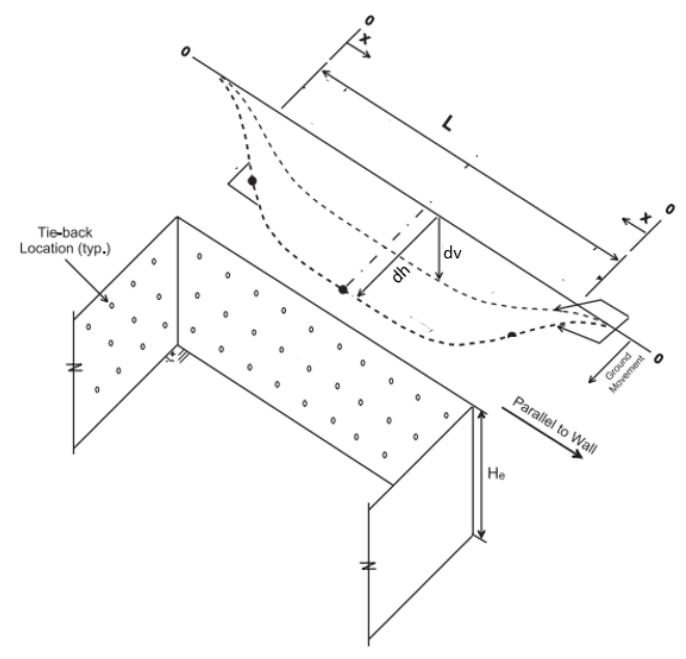

(b)

Figure 1. Deformation Profile (a) Horizontal Wall Movement $(d h)$ and Ground Surface Settlement $(d v)$ Behind the Wall (b) $d h$ and $d v$ Profile Parallel along the wall.

\subsection{System Stiffness}

System stiffness of braced excavation may be affected by many factors. Based on a previous iterative study [20] on the effect of system stiffness parameters, it was found that the practical method by calculating the system stiffness to determine the lateral deformation of the excavation retaining wall using the chart as shown in Figure 2. These parameters consist of wall stiffness, strut spacing, depth, and excavation dimensions which formulated in an equation called a system stiffness factor with the following equation:

$$
K \quad=\frac{E I}{\gamma_{w} h^{4}}
$$

Where:

EI = wall bending stiffness per unit length $(\mathrm{kN} / \mathrm{m} 2 / \mathrm{m})$

$I=$ Moment inertia per length of the wall $(\mathrm{m} 4 / \mathrm{m})$

$\gamma \mathrm{w}=$ Unit weight of water $(\mathrm{kN} / \mathrm{m} 3)$

$h \quad=$ spacing between supports $(\mathrm{m})$ 


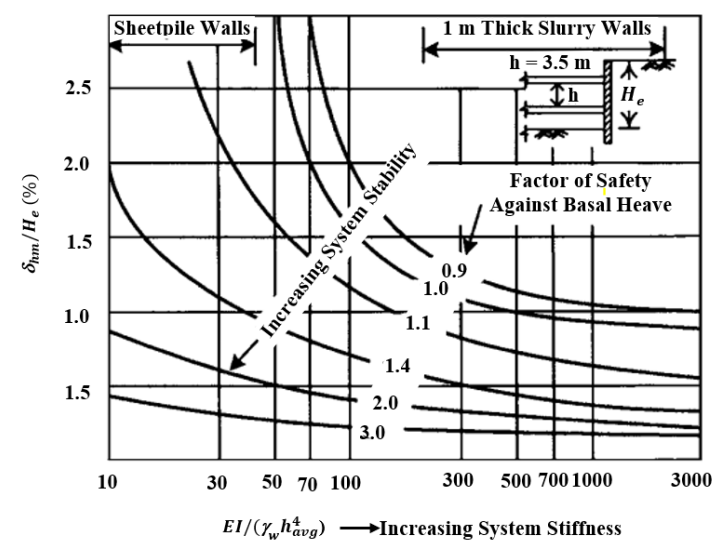

Source: (Clough and O'Rourke, 1990)

Figure 2. Design Curve Lateral Wall Deformation for Excavation

\section{Research Method}

The excavation deformations carried out in this study include horizontal wall movement and ground surface settlement behind the wall. This research determines soil parameters and the excavation geometry model created in 2D and 3D geometry models. In the next step, the system stiffness parameters are determined using the variations in the vertical and horizontal spacing of struts. The results of this modeling are used to analyze the effect of system stiffness which includes spacing of vertical and horizontal supports against the deformations that occur. The research flow chart is shown in Figure 3.

This research was conducted using PLAXIS 2D and PLAXIS 3D software with a calculation basis using the Finite Element Method (FEM). This method is widely used to analyze the stability, deformation, and flow of groundwater. The results of the analysis of finite element-based software are strongly dependent on the input given, including the constitutive soil model [21], [22], [23]. To provide reasonable analysis results, a constitutive soil model should be capable of modeling soil elastoplastic properties. Therefore a hardening soil constitutive model is used. This constitutive model can comply with the elastoplastic properties of the soil by calculating the decrease in the value of stiffness to strain and simultaneously calculating the irreversible plastic strain (a plastic strain that does not recover) [24]-[26]. 


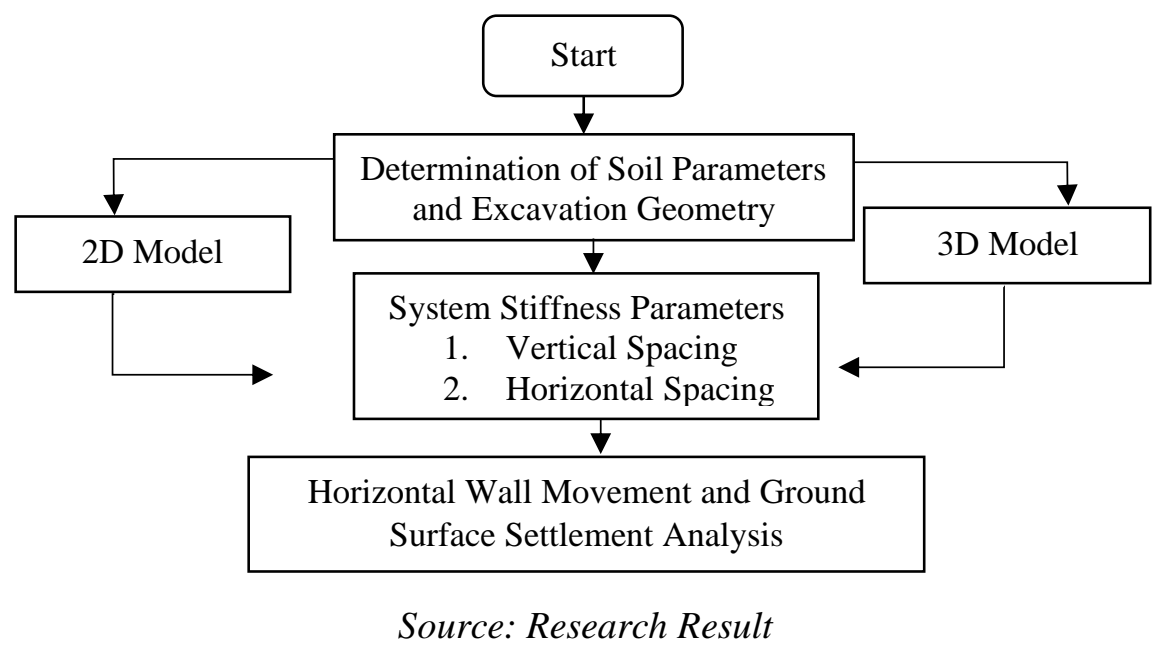

Figure 3. Research Flow Chart

\subsection{Technical Specifications}

\subsubsection{Soil Parameters}

Soil parameters must be provided in advance for numerical analysis. In this research, the soil parameter obtained from the consolidated undrained (CU) triaxial test on clay is shown in Table 1. To model soil parameters of hardening soil [27], there are $\gamma$ which represent the unit weight of soil. The deformation parameters consist of three types of stiffness parameters, including young modulus at $50 \%$ failure stress which represents a small strain modulus $\left(E_{50}^{r e f}\right)$, unloading reloading modulus $\left(E_{u r}^{r e f}\right)$, and oedometer modulus to calculate plastic volumetric strain $\left(E_{\text {oed }}^{r e f}\right)$. Strength parameters used are cohesion $\left(c^{\prime}{ }_{\text {ref }}\right)$ and friction angle $\left(\phi^{\prime}\right)$ to define the failure criteria. It also provided the permeability parameters, $k_{x}$ And $k_{y}$ as hydraulic conductivity of water flows through the soil, the soil profile along the depth remains uniform to simplify the model and limit the deformation factors.

Table 1. Soil Parameters Used for Modeling

\begin{tabular}{ccc}
\hline \multicolumn{2}{c}{ Constitutive Model } & Hardening Soil \\
Parameters & Units & Value \\
\hline$\gamma_{\text {unsat }}$ & {$[\mathrm{kN} / \mathrm{m} 3]$} & 8.67 \\
$\gamma_{\text {sat }}$ & {$[\mathrm{kN} / \mathrm{m} 3]$} & 15.1 \\
$\mathrm{kx}$ & {$[\mathrm{m} / \mathrm{day}]$} & $4 \times 10-6$ \\
$\mathrm{ky}$ & {$[\mathrm{m} / \mathrm{day}]$} & $2 \times 10-6$ \\
$E_{50}^{r e f}$ & {$[\mathrm{kN} / \mathrm{m} 2]$} & 26000 \\
$E_{\text {oed }}^{r e f}$ & {$[\mathrm{kN} / \mathrm{m} 2]$} & 26000 \\
$E_{\text {ur }}^{r e f}$ & {$[\mathrm{kN} / \mathrm{m} 2]$} & 78000 \\
$C^{\prime}$ ref & {$[\mathrm{kN} / \mathrm{m} 2]$} & 10 \\
$\phi$ & {$\left[{ }^{\circ}\right]$} & 33 \\
vur & {$[-]$} & 0.3 \\
\hline
\end{tabular}




\subsubsection{Excavation Geometry}

The excavation geometry used for parametric study has a simple rectangular with dimensions of length, $P, 40$ meters and width, $L, 30$ meters, and excavation depth, He, 17 meters. The excavation geometry developed using PLAXIS 2D and 3D software, as shown in Figure 4.

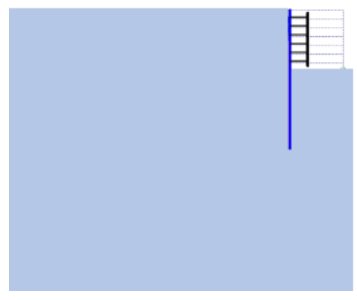

(a)

Source: Research Result

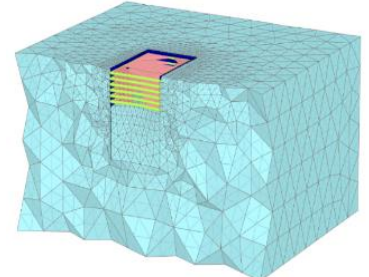

(b)

Source: Research Result

Figure 4. (a) 2D Geometry Model (b) 3D Geometry Model

\subsubsection{Structural Elements}

The structural elements modeled in this analysis include retaining walls using diaphragm walls with a thickness of $h, 80 \mathrm{~cm}$ to a depth, $H, 40$ meters with reinforced concrete material. The supporting systems consist of struts using section properties steel pipe pile (SPP) with a type of rolled steel with a diameter of $609 \mathrm{~mm}$ and a thickness of $12 \mathrm{~mm}$. For connecting the struts to the diaphragm wall, a waller is used with section properties was H-Welded profile type HE 1000x584. The structural parameters used in the analysis are shown in Table 2 and

Table 3.

Table 2. Diaphragm Walls Parameters Used for Modeling

\begin{tabular}{ccc}
\hline Parameters & Units & Value \\
\hline $\mathrm{h}$ & $\mathrm{m}$ & 0.80 \\
$\mathrm{~A}$ & $\mathrm{~m} 2 / \mathrm{meter}$ & 0.80 \\
$I_{1}$ & $\mathrm{~m} 4 / \mathrm{meter}$ & 0.04 \\
$\mathrm{fc}^{\prime}$ & $\mathrm{MPa}$ & 35.00 \\
$\mathrm{E}$ & $\mathrm{kN} / \mathrm{m} 2$ & 27805575 \\
$\gamma$ & $\mathrm{kN} / \mathrm{m} 3$ & 24.00 \\
\hline
\end{tabular}

Source: Research Result

Table 3. Wallers and Struts Properties Used for Modeling

\begin{tabular}{cccc}
\hline \multicolumn{2}{c}{ Structural Elements } & Wallers & Struts \\
\multicolumn{2}{c}{ Section Properties } & HE 1000x584 & SPP.609.12 \\
\hline Parameter & Units & 743.70 & \\
A & $\mathrm{m} 2$ & 78.50 & 225.30 \\
$\gamma$ & $\mathrm{kN} / \mathrm{m} 3$ & 78.50
\end{tabular}




\begin{tabular}{cccc}
\hline \multicolumn{2}{c}{$\begin{array}{c}\text { Structural Elements } \\
\text { Section Properties }\end{array}$} & Wallers & Struts \\
E & $\mathrm{kN} / \mathrm{m} 2$ & 210000000 & SPP.609.12 \\
\hline$I_{2}=I_{x}$ & $\mathrm{~m} 4 / \mathrm{meter}$ & 1246100 & 210000000 \\
$I_{3}=I_{y}$ & $\mathrm{~m} 4 / \mathrm{meter}$ & 33430 & 101000 \\
\hline
\end{tabular}

Source: Research Result

\subsection{Parametric Study}

The parametric study carried out included two different variations in vertical struts spacing, $S v$, and horizontal struts spacing, $S h$, as shown in Table 4 and Table 5, the distance of each strut was varied arithmetic in one direction, and another direction was held constant to evaluate the influence of each variation. The variation of the vertical spacing of the struts causes the different excavation stages in each analysis. This was related to the depth of excavation for each construction step and the position of the vertical struts installation, while the stages of construction of horizontal struts spacing variation were using constant vertical struts spacing 2.5 meters. The excavation stages in each parametric study are shown in Table 6.

Table 4. Variation in Vertical Struts Spacing $(S v)$ Used in Parametric Study

\begin{tabular}{ccc}
\hline No & $S v(\mathrm{~m})$ & $S h(\mathrm{~m})$ \\
\hline 1 & 2.5 & 2.5 \\
2 & 5.0 & 2.5 \\
3 & 7.5 & 2.5 \\
\hline
\end{tabular}

Source: Research Result

Table 5. Variation in Horizontal Struts Spacing (Sh) Used in Parametric Study

\begin{tabular}{ccc}
\hline No & $S v(\mathrm{~m})$ & $S h(\mathrm{~m})$ \\
\hline 1 & 2.5 & 2.5 \\
2 & 2.5 & 5.0 \\
3 & 2.5 & 7.5 \\
\hline
\end{tabular}

Source: $\quad$ Research Result

Table 6. Stages of Construction

\begin{tabular}{|c|c|c|c|c|c|}
\hline \multirow{2}{*}{ No } & \multirow{2}{*}{ Events } & \multirow{2}{*}{ Elevation (m) } & \multicolumn{3}{|c|}{$S v(\mathrm{~m})$} \\
\hline & & & $* 2.5$ & 5.0 & 7.5 \\
\hline 1 & Construction of diaphragm wall & $\begin{array}{l}\text { Top: }+0.00 \mathrm{~m} \\
\text { Toe: }-40.00 \mathrm{~m}\end{array}$ & $\sqrt{ }$ & $\sqrt{ }$ & $\sqrt{ }$ \\
\hline 2 & Excavation Stage 1 & $-2.50 \mathrm{~m}$ & $\sqrt{ }$ & $\sqrt{ }$ & $\sqrt{ }$ \\
\hline 3 & Installation of Struts 1 & $-2.00 \mathrm{~m}$ & $\sqrt{ }$ & & \\
\hline 4 & Excavation Stage 2 & $-5.00 \mathrm{~m}$ & $\sqrt{ }$ & $\sqrt{ }$ & $\sqrt{ }$ \\
\hline 5 & Installation of Struts 2 & $-4.50 \mathrm{~m}$ & $\sqrt{ }$ & $\sqrt{ }$ & \\
\hline 6 & Excavation Stage 3 & $-7.50 \mathrm{~m}$ & $\sqrt{ }$ & $\sqrt{ }$ & $\sqrt{ }$ \\
\hline 7 & Installation of Struts 3 & $-7.00 \mathrm{~m}$ & $\sqrt{ }$ & & $\sqrt{ }$ \\
\hline 8 & Excavation Stage 4 & $-10.00 \mathrm{~m}$ & $\sqrt{ }$ & $\sqrt{ }$ & $\sqrt{ }$ \\
\hline 9 & Installation of Struts 4 & $-9.50 \mathrm{~m}$ & $\sqrt{ }$ & $\sqrt{ }$ & \\
\hline 10 & Excavation Stage 5 & $-12.50 \mathrm{~m}$ & $\sqrt{ }$ & $\sqrt{ }$ & $\sqrt{ }$ \\
\hline 11 & Installation of Struts 5 & $-12.00 \mathrm{~m}$ & $\sqrt{ }$ & & \\
\hline
\end{tabular}




\begin{tabular}{|c|c|c|c|c|c|}
\hline \multirow{2}{*}{ No } & \multirow{2}{*}{ Events } & \multirow{2}{*}{ Elevation (m) } & \multicolumn{3}{|c|}{$S v(\mathrm{~m})$} \\
\hline & & & $* 2.5$ & 5.0 & 7.5 \\
\hline 12 & Excavation Stage 6 & $-15.00 \mathrm{~m}$ & $\sqrt{ }$ & $\sqrt{ }$ & $\sqrt{ }$ \\
\hline 13 & Installation of Struts 6 & $-14.5 \mathrm{~m}$ & $\sqrt{ }$ & $\sqrt{ }$ & $\sqrt{ }$ \\
\hline 14 & Excavation Stage 7 & $-17.00 \mathrm{~m}$ & $\sqrt{ }$ & $\sqrt{ }$ & $\sqrt{ }$ \\
\hline 15 & Construction of Base Slab & $-17.00 \mathrm{~m}$ & $\sqrt{ }$ & $\sqrt{ }$ & $\sqrt{ }$ \\
\hline
\end{tabular}

* Stages of construction for variation of horizontal struts spacing used vertical struts spacing 2.5 meters. Source: Research Result

\section{Results and Discussions}

\subsection{Influence of System Stiffness}

To evaluate the effect of stiffness systems on deformations, the ratio of system stiffness parameters in vertical, $K v$, to horizontal, $K h$, were used based on [20], which compared against normalized deformation with the depth of excavation, $d h / H e$, and $d v / H e$. An increase in the strut spacing causes the system stiffness to decrease.

Table 7. Relationship between the Maximum Deformation and Variation of Struts Spacing

\begin{tabular}{|c|c|c|c|c|c|c|c|}
\hline \multirow{3}{*}{ Model } & \multirow{3}{*}{$\begin{array}{l}\text { Maximum } \\
\text { Deformation }\end{array}$} & \multicolumn{3}{|c|}{$S h=2.5 \mathrm{~m}$} & \multicolumn{3}{|c|}{$S v=2.5 \mathrm{~m}$} \\
\hline & & & Sv & & & $S h$ & \\
\hline & & $2.5 \mathrm{~m}$ & $5.0 \mathrm{~m}$ & $7.5 \mathrm{~m}$ & $2.5 \mathrm{~m}$ & $5.0 \mathrm{~m}$ & $7.5 \mathrm{~m}$ \\
\hline \multirow{2}{*}{$2 \mathrm{D}$} & Horizontal $(d h)$ & 46.84 & 57.68 & 72.59 & 46.84 & 55.31 & 62.20 \\
\hline & Vertical $(d v)$ & -25.90 & -32.16 & -42.52 & -25.90 & -31.10 & -41.49 \\
\hline \multirow{2}{*}{$3 \mathrm{D}$} & Horizontal $(d h)$ & 42.88 & 51.50 & 62.20 & 42.88 & 50.50 & 54.80 \\
\hline & Vertical $(d v)$ & -23.59 & -28.71 & -36.38 & -23.59 & -27.04 & -34.80 \\
\hline
\end{tabular}

Source: Research Result

The effects of variation in struts spacing on the maximum deformation are shown in Table 7. It can be seen that the highest maximum $d h$ value was $72.59 \mathrm{~mm}$, which was obtained from the 2D model at the value of $S v=7.5 \mathrm{~m}$ and $S h=2.5 \mathrm{~m}$. There was an increase in horizontal wall movement of $54.97 \%$ compared to the conditions with values of $S v=2.5 \mathrm{~m}$ and $S h=2.5 \mathrm{~m}$. In contrast, the maximum $d h$ value when $S h=7.5 \mathrm{~m}$ was $62.2 \mathrm{~mm}$, this value was $17 \%$ lower compared to the highest maximum horizontal deformation value for vertical spacing variation at the same distance. For the ground surface settlement value, $d v$, a negative sign (-) is given to indicate that the deformations that occur were in the form of settlement. The highest maximum $d v$ was obtained with $-42.52 \mathrm{~mm}$ in $2 \mathrm{D}$ models at $S v=7.5 \mathrm{~m}$, while the lowest maximum $d v$ values occur when $S h=2.5 \mathrm{~m}$ was $-25.90 \mathrm{~mm}$, which was $64.17 \%$ difference. This indicates that the effect changes in vertical spacing give larger deformation changes than In horizontal spacing, this is also reflected in the results of deformations in other variations in 2D and 3D models, where all the deformation values of the increment of vertical struts spacing 
have a higher value than horizontal spacing. However, it is necessary to analyze each further parameter's significance to obtain the optimum combination of strut spacing.

Table 8. Influence of System Stiffness on Deformation

\begin{tabular}{|c|c|c|c|c|c|c|c|}
\hline \multirow{5}{*}{$\begin{array}{l}\text { Ratio } \\
(\%)\end{array}$} & \multirow{5}{*}{ Model } & \multirow{2}{*}{\multicolumn{3}{|c|}{$\begin{array}{c}\text { Horizontal System Stiffness } \\
K h=12112 \\
\text { Vertical System Stiffness }(K v)\end{array}$}} & \multicolumn{3}{|c|}{$\begin{array}{c}\text { Vertical System Stiffness } \\
K v=12112\end{array}$} \\
\hline & & & & & \multicolumn{3}{|c|}{ Horizontal System Stiffness $(K h)$} \\
\hline & & 12112 & 757 & 150 & 12112 & 757 & 150 \\
\hline & & \multicolumn{3}{|c|}{$K v / K h$} & \multicolumn{3}{|c|}{$K v / K h$} \\
\hline & & 1 & 0.063 & 0.012 & 1 & 16 & 81 \\
\hline \multirow{4}{*}{$\begin{array}{l}d h / \mathrm{He} \\
d v / \mathrm{He} \\
d h / \mathrm{He} \\
d v / \mathrm{He}\end{array}$} & \multirow{2}{*}{$2 \mathrm{D}$} & 0.28 & 0.34 & 0.43 & 0.28 & 0.33 & 0.37 \\
\hline & & 0.15 & 0.19 & 0.25 & 0.15 & 0.18 & 0.24 \\
\hline & \multirow{2}{*}{$3 \mathrm{D}$} & 0.25 & 0.30 & 0.37 & 0.25 & 0.30 & 0.32 \\
\hline & & 0.14 & 0.17 & 0.21 & 0.14 & 0.16 & 0.20 \\
\hline
\end{tabular}

Table 8 presents the maximum $\mathrm{dh} / \mathrm{He}$ values are $0.43 \%$ and $0.37 \%$ which were found when the $K v / K h=0.012$ for $2 \mathrm{D}$ and 3D models, respectively, while the minimum $\mathrm{dh} / \mathrm{He}$ values were $0.28 \%$ and $0.25 \%$ at the $K v / K h$ value $=1$ for $2 \mathrm{D}$ and $3 \mathrm{D}$ models. The result regarding normalized ground surface settlement, $d v / \mathrm{He}$, obtained the similar trend, while the highest values of $d v / \mathrm{He}$ were $0.25 \%$ and $0.21 \%$ at $K v / K h=0.012$ for 2D and 3D models, while the lowest $d v / H e$ values were $0.15 \%$ and $0.14 \%$ at $K v / K h=1$ for 2D and 3D models.

It can be seen that the difference in normalized deformation that occurs was relatively small for variation of vertical and horizontal spacing with the corresponding increment with a maximum difference of about $0.06 \%$ between $K v=150$ and $K h=150$. It is necessary to consider the parameters of the horizontal spacing parameters as important as vertical spacing. In several analyses carried out in retaining walls, the vertical spacing design emphasizes more than horizontal spacing. This study found that the design for vertical and horizontal spacing is equally important, and performing these calculations can be done with 2D plain strain models for simplification. However, 3D models can examine the geometric effects of the excavation.

Figure 5 shows the relationship between the ratio of system stiffness and normalized deformation. It observed that the relationship between the ratio of vertical and horizontal system stiffness to deformation indicates a good approximation to the polynomial equation, which was illustrated by the consistent regression equation was $a x^{2}+b x+c$. The results for each variable obtained from parametric data generated from numerical analysis. 


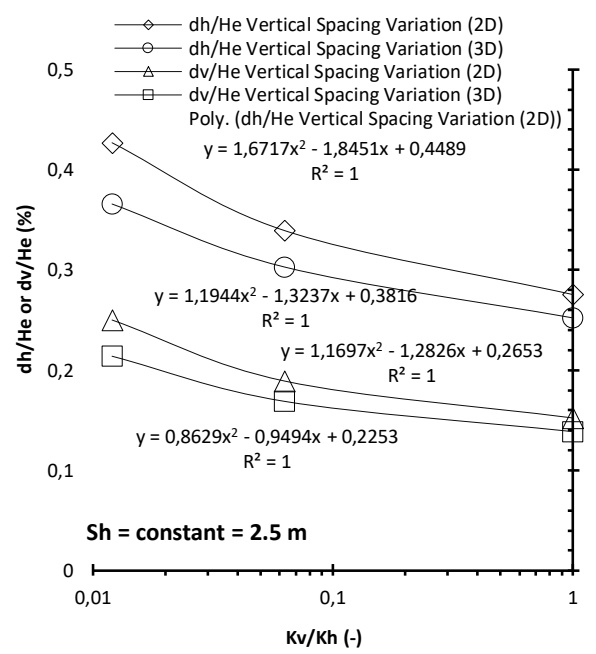

(a)

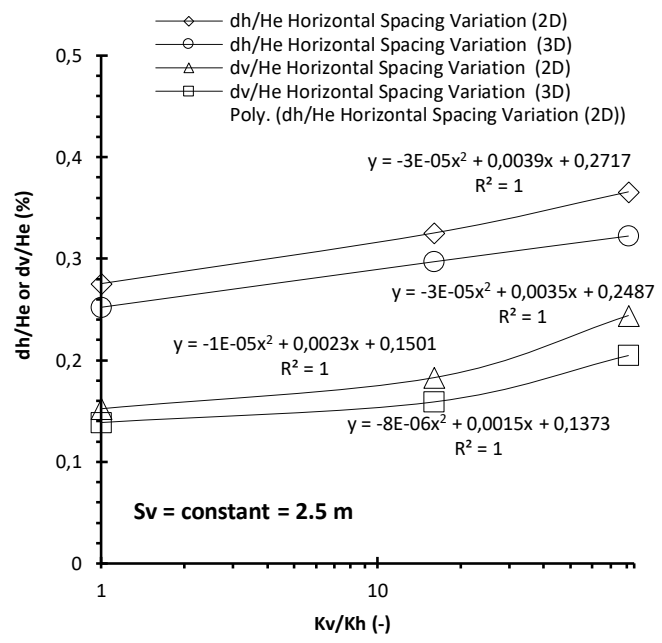

(b)

Source: Research Result

Figure 5. Relationship between System Stiffness Ratio on Normalized Deformation (a) Variation of Vertical Spacing (b) Variation of Horizontal Spacing

\subsection{Effects of 2D and 3D Modeling}

The 2D and 3D modeling effect evaluation refers to the ratio of the maximum value of horizontal wall movement and ground surface settlement. It was found that the horizontal wall movement and ground surface settlement strongly related to 2D and 3D models.

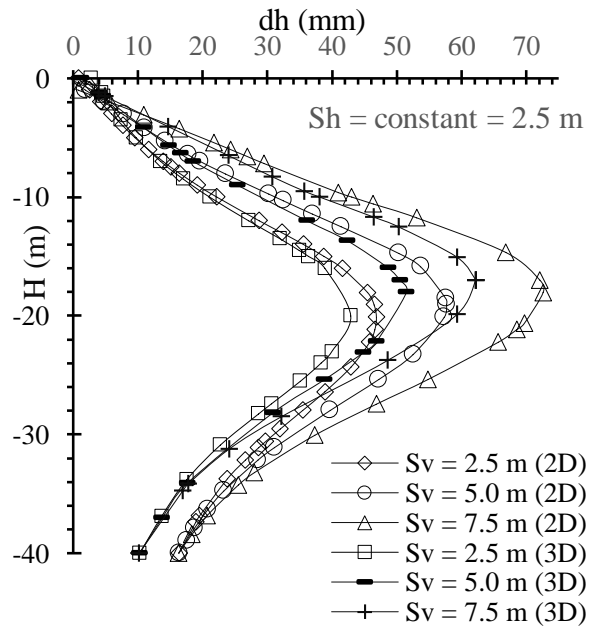

(a)

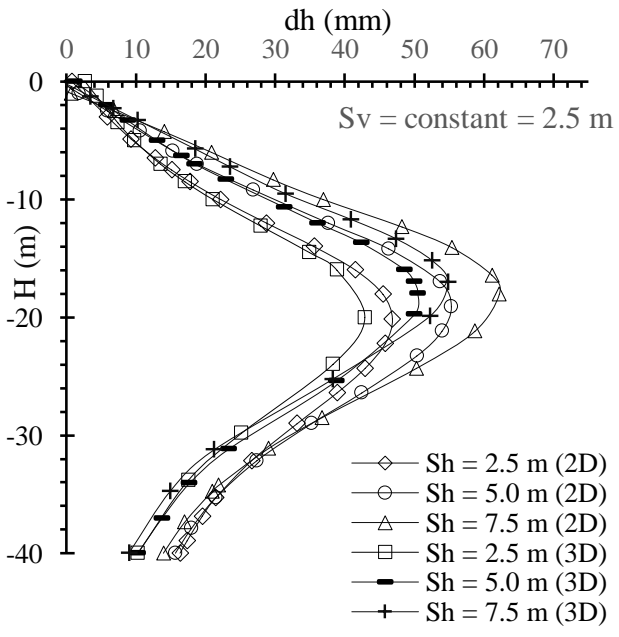

(b)

Source: Research Result

Figure 6. Horizontal Wall Movement (a) Variation of Vertical Spacing (b) Variation of Horizontal Spacing 


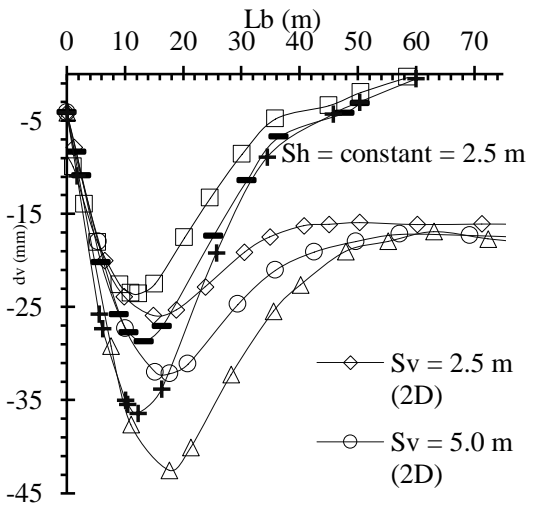

(a)

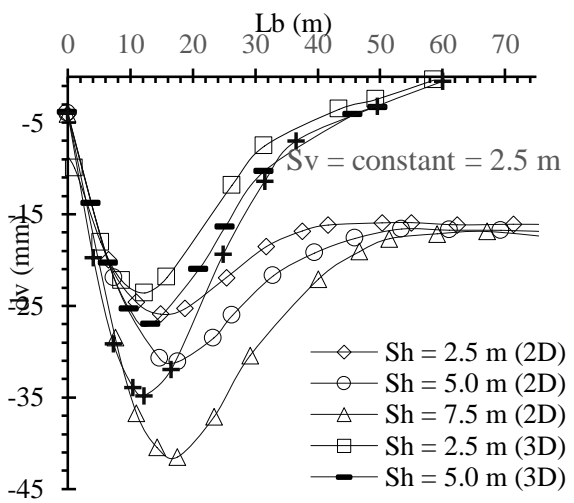

(b)

Source: Research Result

Figure 7. Ground Surface Settlement (a) Variation of Vertical Spacing (b) Variation of

\section{Horizontal Spacing}

Figure 6. shows the horizontal wall movement profile with the depth of excavation. The computed deformation patterns that occur likely have the same consistency, the depth of maximum deflection point was around $17 \mathrm{~m}$ to $20 \mathrm{~m}$, and the system stiffness influenced this depth, the more increment of system stiffness, the deflection point becomes deeper. Moreover, for ground surface settlement can be seen in Figure 7, for 2D models, it was found that the deformation pattern that occurs at a distance from the wall, for $L b>60 \mathrm{~m}, d v$ was constant around $-18 \mathrm{~mm}$, this was different from the 3D model where at the same distance, there was no longer any ground surface settlement.

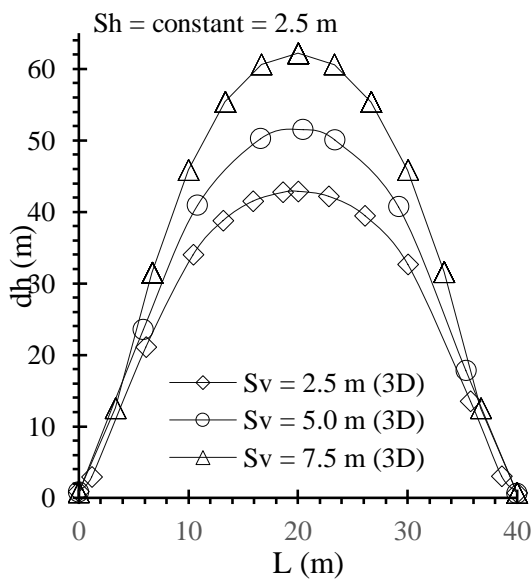

(a)

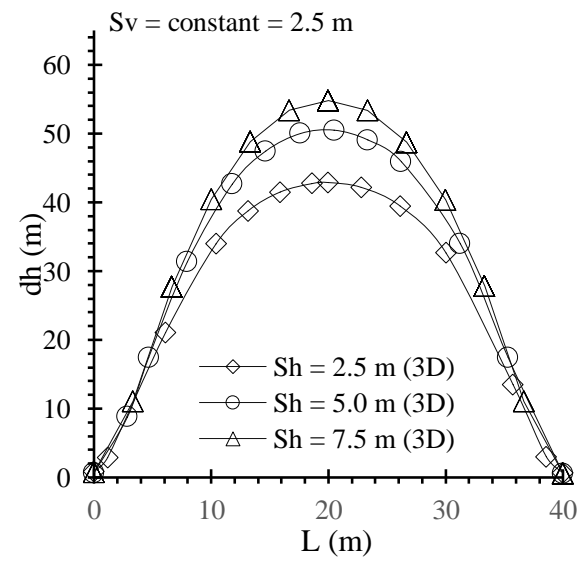

(b)

Source: Research Result

Figure 8. Horizontal Wall Movement Profile along with Longitudinal Section of the Wall in 3D Model (a) Variation of Vertical Spacing (b) Variation of Horizontal Spacing 
The effects of the 3D model can be observed on the longitudinal horizontal wall movement profile along the wall in Figure 8. It can be seen that the horizontal deformation value at the excavation corner has a small value and gradually increases and reaches maximum deformation in the center of the excavation wall. The ratio of the maximum horizontal wall movement in the center of the wall computed by $3 \mathrm{D}$ analysis to the maximum deformation in the plain strain condition is defined as plain strain ratio, PSR [1], [5], [6].

Table 9. Plain Strain Ratio for Various Struts Spacing

\begin{tabular}{|c|c|c|c|c|c|c|}
\hline \multirow{3}{*}{ Plain Strain Ratio (PSR) } & \multicolumn{3}{|c|}{$S h=2.5 \mathrm{~m}$} & \multicolumn{3}{|c|}{$S v=2.5 \mathrm{~m}$} \\
\hline & \multicolumn{3}{|c|}{$S v(m)$} & \multicolumn{3}{|c|}{$\operatorname{Sh}(m)$} \\
\hline & 2.5 & 5.0 & 7.5 & 2.5 & 5.0 & 7.5 \\
\hline$d h_{3 D} / d h_{2 D}$ & 0.92 & 0.89 & 0.86 & 0.92 & 0.91 & 0.88 \\
\hline
\end{tabular}

\section{Source: $\quad$ Research Result}

Table 9 and Figure 9 present the PSR value for various struts spacing, it was found that the highest $P S R$ value was 0.92 at the value of $S v=2.5 \mathrm{~m}$ and $S h=2.5 \mathrm{~m}$, while the lowest $P S R$ value was 0.86 at the value of $S h=2.5 \mathrm{~m}$ and $S v=7.5 \mathrm{~m}$. It is found that the $P S R$ value decreases when the system stiffness value is decreased, meanwhile, when the system stiffness was higher, the PSR value will be higher and closer to 1, which shows that the difference in the 3D and 2D models is relatively small, whereas, the smaller the PSR value indicates that the plain strain calculation results have the significant differences with the $3 \mathrm{D}$ modeling results, where the excavation model is more representative in $3 \mathrm{D}$ in nature.

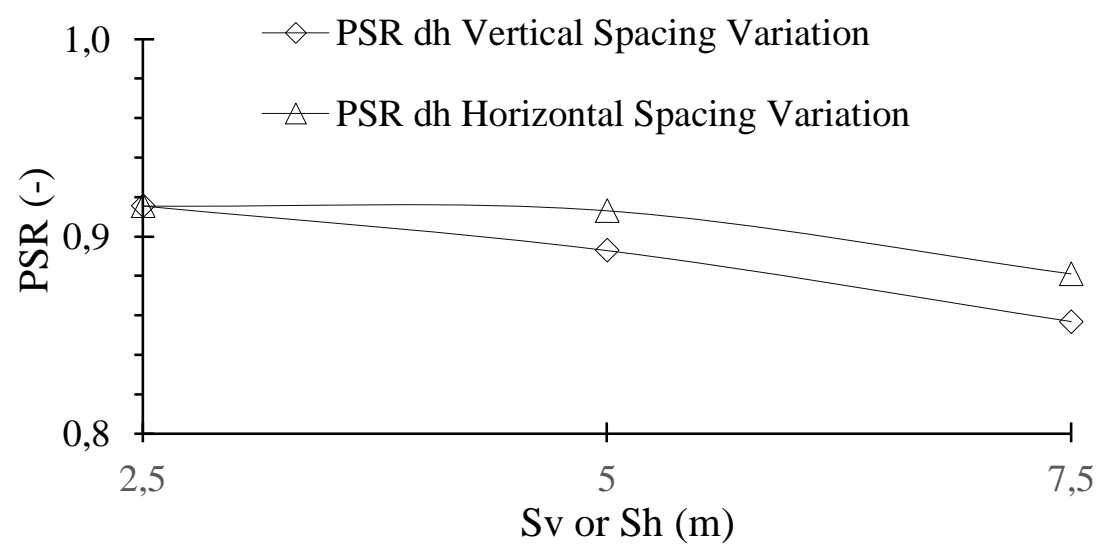

Source: $\quad$ Research Result

Figure 9. Relationship Between Variation of Struts Spacing and Plain Strain Ratio. 


\section{Conclusion and Suggestion}

\subsection{Conclusion}

Based on the results of the analysis carried out, the following conclusions can be obtained:

1. An increase in vertical spacing generally results in a higher increase of the horizontal wall movement and ground surface settlement than an increase in horizontal spacing. However, it should be considered that the difference of normalized deformation to the depth of excavation shows a small value. Hence the design for vertical and horizontal spacing is equally important.

2. The relationship between the ratio of system stiffness in the vertical and horizontal direction to normalized deformation shows a good approximation to the polynomial equation, which was illustrated by the consistent regression with the equation that was $a x^{2}+b x+c$.

3. The horizontal wall movement and ground surface settlement obtained in the 2D plain strain model show a higher value than the 3D model. It is also found that the area of influence on the 2D plain strain model has more distance behind the wall. This is because the 3D model is affected by the corner effect so that the system stiffness in the direction of deformation is higher.

4. To evaluate the difference in horizontal wall movement that occurs in 2D plain strain and 3D models, the plain strain ratio, $P S R$, is used, it is found that the stiffer the excavation system is, the $P S R$ value is closer to 1 , which mean that the difference in the $3 \mathrm{D}$ and $2 \mathrm{D}$ models is relatively smaller.

\subsection{Suggestion}

To provide a comprehensive result on the factor affecting deformation, additional parametric modeling can be added. The results of numerical modeling need to be verified with measurement data in the field so that the reliability of the modeling results can be measured. 


\section{References}

[1] C.-Y. Ou, D.-C. Chiou, and T.-S. Wu, "Three-Dimensional Finite Element Analysis of Deep Excavations," J. Geotech. Eng., vol. 122, no. 5, pp. 337-345, May 1996, doi: 10.1061/(asce)0733-9410(1996)122:5(337).

[2] C.-Y. Ou, B.-Y. Shiau, and I.-W. Wang, "Three-dimensional deformation behavior of the Taipei National Enterprise Center (TNEC) excavation case history," Can. Geotech. J., vol. 37, no. 2, pp. 438-448, 2000.

[3] Y. Tan and B. Wei, "Observed Behaviors of a Long and Deep Excavation Constructed by Cut-and-Cover Technique in Shanghai Soft Clay," J. Geotech. Geoenvironmental Eng. ASCE, vol. 138, no. 1, pp. 69-88, Jan. 2012.

[4] M. Kurnia and P. P. Rahardjo, "Performance Analysis Of 'Toga' Foundation With Cap On Thick Soft Soil Based On Laboratory Models And Finite Element Analysis," UKaRsT, vol. 4, no. 2, p. 222, Oct. 2020, doi: http://dx.doi.org/10.30737/ukarst.v3i2.

[5] R. J. Finno, J. T. Blackburn, and J. F. Roboski, "Three-Dimensional Effects for Supported Excavations in Clay," J. Geotech. Geoenvironmental Eng. ASCE, vol. 133, no. 1, pp. 30-36, Jan. 2007.

[6] C.-H. Wu, C.-Y. Ou, and N. Tung, "CORNER EFFECTS IN DEEP EXCAVATIONSESTABLISHMENT OF A FORECAST MODEL FOR TAIPEI BASIN T2 ZONE,” 2010.

[7] A. Lim and C.-Y. Ou, "Performance and Three-Dimensional Analyses of a Wide Excavation in Soft Soil with Strut-Free Retaining System," Int. J. Geomech., vol. 18, no. 9, p. 05018007, Sep. 2018, doi: 10.1061/(ASCE)GM.1943-5622.0001165.

[8] Z. Y. Orazalin, A. J. Whittle, and M. B. Olsen, "Three-Dimensional Analyses of Excavation Support System for the Stata Center Basement on the MIT Campus," J. Geotech. Geoenvironmental Eng., vol. 141, no. 7, p. 05015001, Jul. 2015, doi: 10.1061/(asce)gt.1943-5606.0001326.

[9] S.-L. Chen, C. Ho, and Y.-C. Kuo, "Three-Dimensional Numerical Analysis of Ground Surface Settlement Induced by the Excavation of Shield Tunnels," in Tunnel Management, Emerging Technologies, and Innovation, May 2011, pp. 80-87, doi: 10.1061/47632(411)11. 
[10] B. Jiang, J. Ma, and J. Chu, "The Influence of Soil Surrounding the Caisson Cutting Edge to Excavation and Sinking,” Jan. 2019, pp. 435-448, doi: 10.1061/9780784482049.043.

[11] Y.-X. Wu, H.-M. Lyu, J. Han, and S.-L. Shen, "Dewatering-Induced Building Settlement around a Deep Excavation in Soft Deposit in Tianjin, China," J. Geotech. Geoenvironmental Eng., vol. 145, no. 5, p. 05019003, May 2019, doi: 10.1061/(asce)gt.1943-5606.0002045.

[12] C. Yang, Y. Chen, Z. Guo, W. Zhu, and R. Wang, "Surface Settlement Control in the Excavation of a Shallow Intersection between a Double-Arched Tunnel and a Connection Tunnel," Int. J. Geomech., vol. 21, no. 4, p. 04021035, Apr. 2021, doi: 10.1061/(asce)gm.1943-5622.0001983.

[13] L. Zhang, X. Wu, and H. Liu, "Strategies to Reduce Ground Settlement from Shallow Tunnel Excavation: A Case Study in China,” J. Constr. Eng. Manag., vol. 142, no. 5, p. 04016001, May 2016, doi: 10.1061/(asce)co.1943-7862.0001087.

[14] R. I. Kusuma, E. Mina, and W. R. Amala, "ANALISIS DEFORMASI LATERAL DIAPHRAGM WALL DAN DEWATERING PADA KONSTRUKSI BASEMENT (Studi kasus: Proyek The Ayoma Apartment, Serpong, Tangerang Selatan)," J. FONDASI, vol. 8, no. 1, Apr. 2019, doi: 10.36055/jft.v8i1.5398.

[15] H. M. Pasaribu, “ANALISIS DEFORMASI GALIAN DALAM PADA TITIK TEPI DINDING DIAFRAGMA DENGAN METODE ELEMEN HINGGA MELALUI STUDI EVALUASI MODEL TANAH,”Educ. Build., vol. 4, no. 1, Jun. 2018, doi: 10.24114/eb.v4i1.10038.

[16] D. W. Apriani, U. Mustofa, and R. Hidayat, "Soil Shear Strength Parameter Analysis Based On Behavior Analysis Of Landslide Case," U KaRsT, vol. 4, no. 2, pp. 163-176, 2020, doi: 10.1016/j.nrjag.2017.12.003.

[17] P. G. Hsieh and C. Y. Ou, "Shape of ground surface settlement profiles caused by excavation," Can. Geotech. J., vol. 35, no. 6, pp. 1004-1017, 1998.

[18] J. Roboski and R. J. Finno, "Distributions of ground movements parallel to deep excavations in clay,” Can. Geotech. J., vol. 43, no. 1, pp. 43-58, Jan. 2006.

[19] G. T. Kung, C. H. Juang, E. C. Hsiao, and Y. M. Hashash, "Simplified Model for Wall Deflection and Ground-Surface Settlement Caused by Braced Excavation in Clays," J. Geotech. Geoenvironmental Eng. ASCE, vol. 133, no. 6, pp. 731-747, Jun. 2007. 
[20] G. Clough, E. Smith, and B. P. Sweeney, "Movement Control of Excavation Support Systems by Iterative Design," Proc., Found. Eng. Congr. Curr. Princ. Pract. ASCE, vol. 2, no. 1 , pp. 869-884, 1989.

[21] M. Rouainia, G. Elia, S. Panayides, and P. Scott, "Nonlinear Finite-Element Prediction of the Performance of a Deep Excavation in Boston Blue Clay," J. Geotech. Geoenvironmental Eng., vol. 143, no. 5, p. 04017005, May 2017, doi: 10.1061/(asce)gt.1943-5606.0001650.

[22] M. A. Nikolinakou, A. J. Whittle, S. Savidis, and U. Schran, "Prediction and Interpretation of the Performance of a Deep Excavation in Berlin Sand," J. Geotech. Geoenvironmental Eng., vol. 137, no. 11, pp. 1047-1061, Nov. 2011, doi: 10.1061/(asce)gt.1943-5606.0000518.

[23] C. Girsang, P. P. Rahardjo, and A. Lim, "Modelling the Response of Single Passive Piles Subjected to Lateral Soil Movement using PLAXIS," Ukarst J. Univ. Kadiri Ris. Tek. Sipil, vol. 5, no. 1, pp. 1-16, 2021, doi: 10.17577/ijertv4is030269.

[24] R. B. . Brinkgreve, S. Kumarswamy, W. . Swolfs, D. Waterman, A. Chesaru, and P. Bonnier, PLAXIS 2016, 2016th ed. Delf: Plaxis bv, 2016.

[25] W. Tang and F. Ye, "The application of PLAXIS software in deformation analysis of Shanghai maglev line due to nearby foundation pit excavation," in CICTP 2019: Transportation in China - Connecting the World - Proceedings of the 19th COTA International Conference of Transportation Professionals, 2019, pp. 226-237, doi: 10.1061/9780784482292.021.

[26] C. Surarak, S. Likitlersuang, D. Wanatowski, A. Balasubramaniam, E. Oh, and H. Guan, "Stiffness and strength parameters for hardening soil model of soft and stiff Bangkok clays," Soils Found., vol. 52, no. 4, pp. 682-697, Aug. 2012, doi: 10.1016/j.sandf.2012.07.009.

[27] J. M. Duncan and C.-Y. Chang, "Nonlinear Analysis of Stress and Strain in Soils," J. Soil Mech. Found. Div., vol. 96, no. 5, pp. 1629-1653, Sep. 1970, doi: 10.1061/jsfeaq.0001458. 